\title{
Insurance Products: Technological Service Delivery Perspective
}

\author{
Adenike Olanrewaju Owolabi (Corresponding author) \\ Department of Financial Studies, Redeemer's University, Ede Osun State, Nigeria \\ Tel: 234-805-102-9341Ｅ-mail: owolabi_olanrewaju@yahoo.com
}

Received: January 26, 2018 Accepted: March 12, 2018 Published: June 2, 2018

doi:10.5296/ber.v8i3.13238 URL: https://doi.org/10.5296/ber.v8i3.13238

\begin{abstract}
The main objective of this study was to investigate the impact of technological service delivery on insurance products. 150 staff of some insurance companies in Osogbo were selected for this study through multistage sampling technique. Data from the questionnaire were coded, categorized and analyzed using Simple Percentage, Pearson product-moment Correlation and Simple Linear Regression analysis. This study concluded that the introduction of technology has significant impact on the efficiency of the Nigerian insurance companies. It was also found that technological service delivery has direct impact on the increase in the purchase of insurance products. It is recommended that Insurance companies in Nigeria should enhance their interest in technological service delivery in order to further improve performance effectiveness in each part of their business operations.
\end{abstract}

Keywords: Technology, Service Delivery, Insurance products, Insurance

\section{Introduction}

From a very long time, facts and means of sending and receiving information are vital and essential in all sphere of life. The development of science and technology has greatly enhanced every aspect of human endeavour. Hence, the global business environment has been revolutionalised by creativity, innovation and technological advancement thereby increasing customers' awareness and availability of wider range of sophisticated products/services. New technologies have significantly impacted business organisations to overcome barriers-cost, time and distance-to global operations. The current business surrounding is very active, changing and undergoes rapid changes as a result of technological new ideas, increased knowledge and request from buyers. Commercial organizations, especially the insurance industry of the 21st century function in a complicated and competitive environment characterized by these changing conditions and highly difficult to predict economic environment. Information Technology has transited the way of insurance sector and their 
corporate friendships are organized worldwide and the specific types of innovative ploys available to enhance the speed and quality of service delivery. Information Technology (IT) is at the focus of attention of this worldwide transition curve. Because of the Information transition, customers have freedom of choice to choose from a wide range of new and innovative products. The Insurance companies are making use of the Information technology applications for better customer service attraction, reduction of cost, new product invention, developmental changes and many more. Recent technology gives the insured better, wider and faster access to products and services. The impact of Information Technology in Insurance business is being felt at an accelerating pace. At present, Insurance companies are giving customers a distinct claim to track claims on-line, entertaining on-line enrollment, eligibility review, financial reporting, and billing and electronic fund transfer.

Most insurance companies in Nigeria have keyed into the usage of ITs at varying degrees, with little success for most. The use of IT in the insurance industry is relevant and beneficial considering the significant role of insurance in the economy. Amongst others, insurance promotes business activity by providing financial intermediary services necessary to induce economic growth (Ward and Zurbruegg, 2000; Liedtke, 2007). The insurance industry consolidation, particularly the recapitalisation, seeks to ensure that the industry contribute positively to the economy (Obaremi, 2007). IT usage has considerately improved operations and performance of businesses in Nigeria (Osabuohien, 2008). Moreover, IT enhances management functions of planning, organising and the nature of services offered in the insurance industry. It has greatly improved insurance operations globally in view of the available innovation devices to enhance the speed and quality of service delivery. The reports and analysis pulled from an information system can assist in the planning, directing, and decision making needs of managers for the organization to achieve its planned objectives.

A study by Madueme (2009) on Nigerian insurance industry shows that information technology enhances efficiency and strengthens service quality. Furthermore Fisher and Kenny (2000) suggested that organizations should infuse information system into their operations so as to enhance competitiveness and facilitate business growth and success. Also Laudon and Laudon (2001) believes that information system are embedded in organizations and are the result of standard operating procedures, workflows, politics, organizational culture and structure. Although organizations have different information systems because they have varying information needs they all strive for competitive advantage through continuous improvements.

There are many ways that organizations may view and use information technology depending on their goals, aims and objectives and O'Brien (2002) agreed with this. Organizations may use IT to strategize; they could as well be content to use IT to support efficient everyday operation. The process of information technology adoption and use is critical to deriving the benefits of information technology (Karahanna et al, 1999). The seamless storage retrieval, sorting, filtering distribution and sharing of information can lead to substantial gains in production, distribution, marketing and creation of new products and services. Businesses, large or small rely on quality information for just about everything they do (Mescon et al, 1999) and today computers play a central role in communications, especially with business 
and commercial activities. The Internet, electronic mail, videoconferencing are some of the capabilities of computer systems in recent times. Traditionally, information systems were designed to work in the immediate workplace environment. But recent developments in concepts and design of technologies have greatly considered the possibility of work outside offices and the work place, and have come up with a number of interesting discoveries and design. Thanks to nanotechnology, miniaturized devices such as laptops, palm tops and memory cards now come in handy for business. According to Alter, (2002), without the technical progress, new ways of doing and managing work would not have been feasible. With respect to insurance business in Nigeria, quite a number of benefits have been derived from the adoption and use of ITs over the years; two of the most prominent benefit includes faster means of communication and timeliness of operation. A technology such as video conferencing has made online real-time interaction with partners and associates located outside the headquarters a reality. Through their websites there is room for feedback and interaction with customers and potential policy holders. Vital documents, information and resources are now shared and exchanged seamlessly online. This mechanism makes it very easy to process claims and maintain policies. As a result, understanding the influence of technological service delivery on insurance products is therefore imperative. This study examines insurance products from technological service delivery perspective.

\subsection{Statement of the Problem}

There are number of questions regarding the ever present impact of technological service delivery on insurance products in Nigeria. Most insurance firms in Nigeria are yet to employ information system in their operations, and the few that have employed the system are yet to identify its impact on their operations and product. Therefore the need to understand how information system investment affects the Nigerian insurance business value is an important issue. Therefore this study will clarify how information system impacts the Nigerian insurance industry in the wider context. Therefore the need to evaluate the rate of change that information system investment has caused in Nigerian insurance industry in terms of creativity and innovation within the organization towards achieving competitive advantage in the market place remains a subject of contention in the insurance industry and national economy of Nigeria.

\subsection{Objectives of the Study}

The specific objectives of this study are to:

* ascertain whether the introduction of technology in the insurance sector has enhanced efficiency in Nigerian insurance companies.

* find out whether the customers are satisfied since the implementation of technology in Nigeria insurance companies.

* investigate whether technological service delivery has direct impact on increase in purchase of insurance products. 


\section{Methods}

Cross sectional design was used to determine the impact of technological service delivery on insurance products. The researcher used this design since no part of the result was manipulated but was explained as occurred in the study. The research design used in this study was the survey method through the use of questionnaire to gather information from insurance companies in Osun State on effect of technological service delivery on insurance products and which was used to generate data. The study adopted survey because it is interested in observing what is happening to the variables without making any attempt to control or manipulate them. The target population is made up of all the insurance companies staff randomly selected in Osun State. The inclusion criteria are that the insurance companies' staff must have worked for at least 2 years in the insurance industry.

The study population will be all the available insurance companies staff that matched the inclusion criteria mentioned below.

\subsection{Inclusion Criteria}

Educated employee working in the insurance companies in Osun State, Insurance companies employees who are willing to participate in the study, Insurance companies' employees who are available at the time of data collection.

\subsection{Sample Size Determination and Sampling Technique}

Multistage sampling technique was employed to select study participants. The sampling is done in two stages, in stage one, cluster sampling was employed to choose some insurance companies, while in stage two simple random sampling was used to select participants in this study while in stage three, eligible respondents were selected by convenient sampling from each insurance companies and questionnaires were served to 150 staff while 141 questionnaires were retrieved.

\subsection{Procedure for Data Collection and Analysis}

A self-designed and structured questionnaire was considered as the data collection instrument for the study. The questionnaire was designed to measure the effect of technological service delivery on insurance products. The construction of the questionnaire was based on the five point standardized Likert scale. The direct method approach was used in the opinion survey. The copy of questionnaire was administered to respondents and the respondents were asked to tick the options in order to reflect their opinion. Regression techniques were used to test the three hypotheses so as to know the impact of technological service delivery on insurance products.

\section{Data Analysis}

3.1 Analysis of Data related to Insurance Products: Technological Service Delivery Perspective 
Table 1. The Impact of Technological Service Delivery on Insurance Products

\begin{tabular}{|c|c|c|c|c|c|c|c|c|c|c|}
\hline & \multicolumn{2}{|c|}{ Strongly Agree } & \multicolumn{2}{|c|}{ Agree } & \multicolumn{2}{|c|}{ Undecided } & \multicolumn{2}{|c|}{ Disagree } & \multicolumn{2}{|c|}{ Strongly Disagree } \\
\hline & Freq. & Percent & Freq. & Percent & Freq. & Percent & Freq. & Percent & Freq. & Percent \\
\hline $\begin{array}{l}\text { Information technology have impact on } \\
\text { insurance product }\end{array}$ & 38 & 26.95 & 64 & 45.39 & 0 & 0.00 & 22 & 15.60 & 17 & 12.06 \\
\hline $\begin{array}{l}\text { Technological service delivery enhance } \\
\text { promptness in claims handling process }\end{array}$ & 23 & 16.31 & 59 & 41.84 & 11 & 7.80 & 28 & 19.86 & 20 & 14.18 \\
\hline $\begin{array}{l}\text { There is a better delivery of our products } \\
\text { due to the adoption of information } \\
\text { technology in our organization }\end{array}$ & 45 & 31.91 & 71 & 50.35 & 4 & 2.84 & 12 & 8.51 & 9 & 6.38 \\
\hline $\begin{array}{l}\text { Technological service delivery leads to } \\
\text { increases in productivity and } \\
\text { competitiveness in insurance company }\end{array}$ & 30 & 21.28 & 58 & 41.13 & 13 & 9.22 & 23 & 16.31 & 17 & 12.06 \\
\hline $\begin{array}{l}\text { Technological service delivery enhances } \\
\text { organization's image which leads to } \\
\text { more sales of insurance products }\end{array}$ & 37 & 26.24 & 56 & 39.72 & 17 & 12.06 & 20 & 14.18 & 11 & 7.80 \\
\hline $\begin{array}{l}\text { Information technology facilitates } \\
\text { growth in research activity }\end{array}$ & 68 & 48.23 & 73 & 51.77 & 0 & 0.00 & 0 & 0.00 & & 0.00 \\
\hline $\begin{array}{l}\text { There is a better accounting system in } \\
\text { this organization because of } \\
\text { technological service delivery }\end{array}$ & 56 & 39.72 & 69 & 48.94 & 0 & 0.00 & 9 & 6.38 & 7 & 4.96 \\
\hline $\begin{array}{l}\text { Implementation of technology in the } \\
\text { Nigerian Insurance Companies have } \\
\text { positive influence on customers } \\
\text { satisfaction }\end{array}$ & 41 & 29.08 & 73 & 51.77 & 5 & 3.55 & 13 & 9.22 & 9 & 6.38 \\
\hline $\begin{array}{l}\text { Technological service delivery enable } \\
\text { has direct impact on the increase in the } \\
\text { purchase of insurance products }\end{array}$ & 39 & 27.66 & 72 & 51.06 & 6 & 4.26 & 15 & 10.64 & 9 & 6.38 \\
\hline $\begin{array}{l}\text { Information technology provides more } \\
\text { timely and accurate information }\end{array}$ & 44 & 31.21 & 75 & 53.19 & 4 & 2.84 & 9 & 6.38 & 9 & 6.38 \\
\hline $\begin{array}{l}\text { Technological service delivery provides } \\
\text { better communication network between } \\
\text { insureds' and insurance companies }\end{array}$ & 39 & 27.66 & 68 & 48.23 & 12 & 8.51 & 15 & 10.64 & 7 & 4.96 \\
\hline $\begin{array}{l}\text { The introduction of technology in the } \\
\text { insurance sector has enhanced efficiency } \\
\text { in Nigerian insurance companies }\end{array}$ & 51 & 36.17 & 74 & 52.48 & 5 & 3.55 & 7 & 4.96 & 4 & 2.84 \\
\hline
\end{tabular}

\section{Source: Computed by Author, 2018}

Table 1 describes the impact of technological service delivery on insurance products. $72.34 \%$ of the 141 respondents concurred (Strongly Agree and Agree) that "information technology has impact on insurance product", 58.15\% agreed (Strongly Agree and Agree) that "Technological service delivery enhance promptness in claims handling process", $82.26 \%$ agreed (Strongly Agree and Agree) that "there is a better delivery of our products due to the adoption of information technology in our organization", 62.41\% concurred (Strongly Agree and Agree) that "Technological service Delivery leads to increases in productivity and competitiveness in insurance company", 65.96\% concurred (Strongly Agree and Agree) that "Technological Service Delivery enhances organization's image which leads to more sales of insurance products", all of the staff of insurance companies that participated in this study agreed (Strongly Agree and Agree) that "information technology facilitates growth in research activity", $88.66 \%$ concurred (Strongly Agree and Agree) that "there is a better 
accounting system in this organization because of technological service delivery", $80.85 \%$ concurred (Strongly Agree and Agree) that "implementation of technology in the Nigerian Insurance companies have positive influence on customers satisfaction", 78.72\% concurred (Strongly Agree and Agree) that "technological service delivery enable has direct impact on the increase in the purchase of insurance products", 84.4\% concurred (Strongly Agree and Agree) that "information technology provides more timely and accurate information", 75.89\% concurred (Strongly Agree and Agree) that "technological service delivery provides better communication network between the insured and insurance companies", $88.65 \%$ concurred (Strongly Agree and Agree) that "the introduction of technology in the insurance sector has enhanced efficiency in Nigerian insurance companies".

\subsection{Testing of Hypotheses}

3.2.1 $\mathrm{H}_{01}$ : The Introduction of Technology Has No Significant Impact on the Efficiency in the Nigerian Insurance Companies

Table 2

\begin{tabular}{|l|l|l|l|l|l|l|l|}
\hline Variable & Label & Parameter Estimate & Standard Error & $\mathrm{t}$ Value & $\operatorname{Pr}>|\mathrm{t}|$ & \\
\hline Intercept & Intercept & 0.07692 & 0.13624 & 0.56 & 0.5732 & R-Square & 0.7244 \\
\hline & Introduction of Technology & 1.18935 & 0.06222 & 19.12 & $<.0001$ & Adj R-Square & 0.7224 \\
\hline
\end{tabular}

a. Predictors: (Constant), Introduction of Technology.

b. Dependent Variable: Efficiency in the Nigerian Insurance.

Table 2 reveals the degree of impotence of the introduction of technology on the efficiency in the Nigerian insurance companies. The introduction of technology has impact on the efficiency in the Nigerian insurance companies by $72.44 \%$, and the remaining $27.56 \%$ is explained by other things that can influence the efficiency in the Nigerian insurance companies but not included in this particular model. As depicted in Table 2, the estimates of the model coefficients for $\beta_{0}$ (Intercept) is 0.07692 , and $\beta 1$ (Introduction of Technology) is 1.18935. Therefore, the estimated model between Introduction of Technology and Efficiency in the Nigerian Insurance is presented thus:

Efficiency in the Nigerian Insurance $=0.07692+1.18935$ Introduction of Technology.

The regression equation shows that "the introduction of technology in insurance companies has positive relationship with efficiency in the Nigerian insurance companies". It implies a unit improvement in the usage of technology will bring about efficiency in the Nigerian insurance companies by 1.18935 .

\subsubsection{Hypothesis Two}

$\mathrm{H}_{02}$ : There is no significant relationship between customer's satisfaction and the implementation of technology in the Nigerian Insurance Companies.

In testing whether there is any relationship between customer's satisfaction and the implementation of technology in the Nigerian Insurance Companies, this study makes use of Pearson product-moment correlation. "The sign and the absolute value of a correlation 
coefficient describes the direction and magnitude of the relationship between two variables. The correlation $r$ value requires both a magnitude and a direction of either positive or negative. It may take on a range of values from -1 to 0 to +1 , where the values are absolute and no dimensional with no units involved. A correlation coefficient of zero indicates that no association exists between the measured variables. The closer the $r$ coefficient approaches \pm 1 , regardless of the direction, the stronger is the existing association indicating a more linear relationship between the two variables. The strength of the correlation is not dependent on the direction or the sign". The result of this correlation analysis is presented in Table 3A

Table 3A. Simple Statistics

\begin{tabular}{|l|l|l|l|l|l|l|l|}
\hline Variable & $\mathrm{N}$ & Mean & Std Dev & Sum & Minimum & Maximum & Label \\
\hline $\begin{array}{l}\text { The Implementation of Technology in the } \\
\text { Nigerian Insurance Companies }\end{array}$ & 141 & 2.48936 & 1.15645 & 351.00000 & 1.00000 & 5.00000 & 141 \\
\hline Customers Satisfaction & 141 & 2.83688 & 1.08644 & 400.00000 & 1.00000 & 5.00000 & 141 \\
\hline
\end{tabular}

Table 3B. Pearson Correlation Coefficients, $\mathrm{N}=141$ Prob $>|\mathrm{r}|$ under H0: Rho=0

\begin{tabular}{|l|l|l|}
\hline & $\begin{array}{l}\text { The Implementation of Technology } \\
\text { in the Nigerian Insurance Companies }\end{array}$ & Customers Satisfaction \\
\hline $\begin{array}{l}\text { The Implementation of Technology in the } \\
\text { Nigerian Insurance Companies }\end{array}$ & 1.00000 & $\begin{array}{l}0.87696 \\
<.0001\end{array}$ \\
\hline Customers Satisfaction & $\begin{array}{l}0.87696 \\
<.0001\end{array}$ & 1.00000 \\
\hline
\end{tabular}

According to the data presented in Table 3B, the correlation between customers satisfaction and the implementation of technology in the Nigerian insurance companies is a positive and very strong relationship $(r=0.87696)$. The analysis presented in Table 3B reveals that the relationship between customers satisfaction and the implementation of technology in the Nigerian insurance companies is significant since the P-value is <.0001. Considering the "Coefficient of Determination", since the correlation, customer's satisfaction and the implementation of technology in the Nigerian insurance companies $(r)$ is 0.87696 ; then, the coefficient of determination is 0.7690588 . The outcome indicates that $76.91 \%$ of the variance of customer's satisfaction can be explained by the implementation of technology in the Nigerian insurance companies. The study, therefore, concludes that "there is a significant relationship between customer's satisfaction and the implementation of technology in the Nigerian insurance companies". This implies that, as there is improvement in implementation of technology in the Nigerian insurance companies there will be customer's satisfaction.

\subsubsection{Hypothesis Three}

$\mathrm{H}_{03}$ : Technological service delivery has no direct impact on the increase in the purchase of insurance products.

Table 4. Summary of Regression Analysis of Technological Service Delivery on Increase in the Purchase of Insurance Products

\begin{tabular}{|l|l|l|l|l|l|l|l|l|}
\hline \multicolumn{4}{|c|}{} & \multicolumn{3}{l|}{ Model Summaryb } \\
\hline Variable & Label & Parameter Estimate & Standard Error & $\mathrm{t}$ Value & $\operatorname{Pr}>|\mathrm{t}|$ & & \\
\hline Intercept & Intercept & 0.00429 & 0.06585 & 0.07 & 0.9481 & R-Square & 0.9399 \\
\hline & Technological Service Delivery & 1.01099 & 0.02169 & 46.62 & $<.0001$ & Adj R-Square & 0.9395 \\
\hline
\end{tabular}


a. Predictors: (Constant), Technological Service Delivery.

b. Dependent Variable: Increase in the Purchase of Insurance Products.

Table 4 reveals the degree of impact of technological service delivery on the increase in the purchase of insurance products; technological service delivery have $93.99 \%$ influence on the increase in the purchase of insurance products, and the remaining $6.01 \%$ is explained by other things that can increase in the purchase of insurance products but not included in this particular model. As depicted in Table 4, the estimates of the model coefficients for $\beta_{0}$ (Intercept) is 0.00429 , and $\beta 1$ (Technological Service Delivery) is 1.01099. Therefore, the estimated model between Introduction of Technology and Technological Service Delivery is presented thus: Increase in the Purchase of Insurance Products $=0.00429+1.01099$ Technological Service Delivery. The regression equation shows that technological service delivery has positive relationship with increase in the purchase of insurance products. It implies a unit improvement in technological service delivery will increase the purchase of insurance products by 1.01099 .

\section{Conclusion}

The technological service delivery helps insurance companies to effectively integrate into the global market. The insurance industry is crucial for a country's advancement. This review endeavours to find out how significant and successful technological service delivery is to insurance products and furthermore, to analyze connection between "customers satisfaction and the relationship between implementation of technology in the Nigerian Insurance Companies". In any case, the review found that "the introduction of technology has significant impact on the efficiency of the Nigerian insurance companies. This review is consistent with others, for example, Hyvonen (2007), among others. The Internet has given fresh dispersion channels to insurance products. The technological service delivery has additionally empowered the insurance companies to enhance new products, give better customer service, profound and more extensive insurance coverage to them. This review likewise infers that "technological service delivery has direct impact on the increase in the purchase of insurance products". This is steady with the discoveries on past reviews on technological service delivery, which assert that delivery usage thoughtfully enhanced insurance products in Nigeria (Osabuohien, 2008).

\section{Recommendations}

Some recommendation which, if executed could play an essential part in enhancing insurance products in Nigeria. The following policy considerations are recommended:-

*Insurance companies should accumulate applicable information as regards factors that may help to contribute genuinely to the usefulness of information technology in successful service delivery.

*Customer relationship management with satisfactory technological service delivery facilities should be appropriately looked into in every aspect of operation in the insurance industry.

*Insurance companies should engage the services of qualified proficient and advisors to 
meticulously understudy the required and expected roles Information technology are to play in insurance products.

*The provision of online insurance services should be exceptionally prescribed to enhance service delivery;

*Insurance companies in Nigeria should enhance their interest in technological service delivery in order to further improve performance effectiveness in each part of their business operations.

*Insurance companies should pool their assets together so as to organize seminars, workshops and symposia to enlighten both imminent and existing insurance customers on the need to grasp the utilization of IT in their different dealings.

\section{References}

Alter, S. (2002). Information systems: foundation of E-Business. 4th Edition, NH USA Prentice Hall.

Fisher, B., \& Kenny, R. (2000). Introducing a business information system into an engineering company. Journal of Information, Knowledge and Systems Management, 2, 207-221.

Hyvönen, J. (2007). Strategy, performance measurement techniques and information technology of the firm and their links to organizational performance. Management Accounting Research, 18(3), 343-366. https://doi.org/10.1016/j.mar.2007.02.001

Karahanna, E., Straub, D. W., \& Chavarny, N. L. (1999). Information Technology Adoption Across Time: A Cross-Sectional Comparison of Pre-Adoption and Post-Adoption Beliefs, Management Information Systems Research Center, University of Minnesota. 23(2), 183-213. https://doi.org/10.2307/249751

Laudon, D. P., \& Laudon, J. P. (2001). Management Information Systems: Organization and Technology in the Network Enterprises, 4th ed. Prentice Hall International in U.S

Liedtke, P. K. (2007). What's insurance to a modern economy?. The Geneva Papers on Risk and Insurance - Issues and Practice, 32(2), 211-221.

https://doi.org/10.1057/palgrave.gpp.2510128

Madueme, I. S. (2009). Evaluation of the impact of information communication technology on banking efficiency using the transcendental logarithmic production function and camel rating. International Journal of Engineering Science Technology, 2(1), 1-6.

Mescon, M. H., Bovee, C. L., \& Thill, J. V. (1999). Business Today. 9th edition Prentice Hall, Upper Saddle River.

Obaremi, N. (2007). Nigeria insurance special report: Big is beautiful, African Business, 4, 51-62.

O’Brien, J. A. (2002). Management Information Systems: Managing Information Technology 
in the E. Business Enterprise, 5th Edition, NY, USA :McGraw - Hill Irwin, 530p.

Osabuohien, E. (2008). ICT and Nigerian Banks Reforms: Analysis of anticipated impacts in selected banks. Global Journal of Business Research, 2(2), 67-76.

Ward, D., \& Zurbruegg, R. (2000). Law, politics and life insurance consumption in Asia. The Geneva Papers on Risk and Insurance - Issues and Practice, 27(3), 395-412.

https://doi.org/10.1111/1468-0440.00181

\section{Copyright Disclaimer}

Copyright for this article is retained by the author(s), with first publication rights granted to the journal.

This is an open-access article distributed under the terms and conditions of the Creative Commons Attribution license (http://creativecommons.org/licenses/by/3.0/). 